(REVIEW ARTICLE)

\title{
Critical analysis of physiological action of nasya w.s.r to Sneha Nasya
}

\author{
Roshni KP \\ HOD- Kriyasarira Sri Jayendra Saraswathi Ayurveda College Chennai-600123.
}

Publication history: Received on 18 January 2020; revised on 25 January 2020; accepted on 27 January 2020

Article DOI: https://doi.org/10.30574/wjarr.2020.5.2.0013

\begin{abstract}
Ayurveda has described two-fold treatments for diseases, sodhana (elimination) and samana (alleviation) karma. Sodhana includes panchakarma (five procedures of treatment) which is used to purify the body by removing the vitiated doshas (Bio-energies) of body. All five panchakarma procedures act specifically on specific doshas. Sneha nasya i.e, administration of medicated oil through nasal cavities is one of the Panchakarma procedure which specifically used to treat urdhva jatrugata vyadhi (disease of head and neck region) generated by vitiated kapha dosha. According to Ayurveda, nose is the gateway of siras -cranial cavity, it can provide direct connectivity to cranial cavity and can transfer the administrated medicines from nose directly to cranial cavity. This is why nasya karma is used to treat diseases of head region which are generated by vitiated kapha dosha.

Medicated sneha has lipid soluble substances which gets easily absorbed by mucous membrane of nasal cavity and get easily transmitted to cranial cavity. The anatomical connectivity of nose with cranial cavity has been proved by modern science also. The direct nerve supply from CNS and the rich vascular supply to nasal cavity help to understand probable mode of action of nasya karma. Understanding of physiological action of sneha nasya karma will help to develop more specific and effective medicine for various urdhva jatrugatha vyadhi.
\end{abstract}

Keywords: Nasya; Sneha; Panchakarma; Nasal cavity

\section{Introduction}

According to Ayurveda for the treatment of the disease two types of basic line of treatment protocols are used, one is sodhana chikitsa and the other is samana. Sodhana chikitsa helps to remove impurities of the vitiated doshas from the body to treat diseases. Samana chikitsa is helping to alleviate the vitiated doshas to eradicate the sign and symptoms produced by the vitiated doshas. Sodhana includes five procedures which together called as Panchakarma. By implementing these procedures vitiated doshas can be removed from the body. Panchakarmas help not only to eradicate the diseases but also to maintain the health condition of the body. Nasya is one of the five procedures of Panchakarma. Administration of the medicine or medicated oil through the nostrils is called nasya. ${ }^{[1]}$ As vagbhata has said, nose is the doorway to cranial cavity. ${ }^{[2]}$ Hence the nasya karma provides the easiest way to convey the medicine to eradicate the urdhva jattrugata vyadhi. According to modern science nasal cavity opens directly into the frontal, maxillary and sphenoidal sinuses. The olfactory nerve is also present at the base of the nose. These conditions help to convey the medicated oil administrated through the nose to the cranial cavity. Medicated sneha used for nasya karma helps to reduce the vitiated doshas in the head region.

The scientific physiological action of the sneha nasya can be predicted by correlation of all the fact related with anatomical aspect of the nose and physiology of the absorption and possible transmission of the medicated sneha dravyas.

\footnotetext{
${ }^{*}$ Corresponding author

E-mail address: roshnibalesh@yahoo.com
} 


\section{Nasya}

According to Sushrutha, administration of medicine or medicated oil (siddha sneha) through the nostrils is called nasya karma. Nasya karma is basically used for the sodhana of upper part of the body. In Ayurveda head region is considered the most important part of the body which is the site of kapha dosha. For kapha predominant urdhva jatrugata vyadhi nasya is considered as the best Panchakarma. And as the nose is considered the gate way of the body, the medicines are administered through the nostrils.

\subsection{Types of nasya}

Acharya charaka has classified the nasya according to the form of medication used for the nasya karma. They are navana, avapida, dhmapana, dhuma and prathimarsha nasya. ${ }^{[3]}$ Acharya vagbhata had classified nasya types according to it's action on the body. They are the three types- rechana, tarpana and samana.. ${ }^{[4]}$ According to Sushrta, Nasya is basically of two types- shirovirechana and snehananasya. Snehnanasya of sushruta is same as that of Navananasya of Charaka.

\subsection{Snehana Nasya}

Plane Sneha like ghrita(ghee), oil or other Siddha Sneha (medicated oils) can be used for Nasya karma. Sushruta has further described that the one which is used in sirahsunyata, the one which gives strength to the neck, shoulder and chest regions, the one which increases the eye sight, that Snehanasya is known as nasya in general..5]

Vagbhata has stated taila is the best Sneha to use on the daily basis for the Nasya karma. ${ }^{[6]}$ As head is the site of the kaphadosha and taila has kaphadosha shamaka properties taila reduces the vitiated kapha dosha.

Another form of snehanasya is described under the headings of Marshanasya and Pratimarsha Nasya. In these types of Snehanasya, different Snehamatra is used. According to Vagbhata, 2 bindhu (drops) of Sneha in each nostril is given for Pratimarsha Nasya and 10 bindhu(drops) of sneha in each nostril is given in for Marshanasya.[7] Marsha Nasya is given in the diseased condition. Here age and season should be considered. Pratimarsha snehanasya can be given twice a day - In the morning and evening to any person in any season. Marsha Nasya is highly effective. Pratimarsha Nasya is less potent and take long time to act but has similar effect as that of the Marsha Nasya. Marsha snehanasya may have some complications due to improper administration but pratimarsha Nasya has no side effects or complicatiom as such.[8]

To understand the actions of snehanasya, we should know nasal anatomy in detail. Similarly, physiology of the nose in absorption of the sneha nasya is also very important in understanding the action of the sneha nasya.

\subsection{Anatomical aspect of Nasal Cavity}

The two nasal cavities are the uppermost part of the respiratory tract and contain the olfactory receptors. The smaller anterior region of the cavities is enclosed by the external nose whereas the large posterior region are more central within the skull. The openings of the para-nasal sinuses are the extension of the nasal cavity into the cranial cavity. Four para nasal sinuses are the ethamoidal, sphenoidal, maxillary and frontal sinuses. They develop as outgrowth from the nasal cavities and are lined by the mucous membrane. The nasal cavity is related with the anterior and middle cranial fossae, orbit and paranasal sinuses. The superior aspect of sphenoidal sinus is related with the hypophysis, the optic nerves, optic chiasma and literally to the cavernous sinus and internal carotid artery ${ }^{[9]}$

The cribriform plate is a part of the ethmoid bone, forms the portion of the roof of the nasal cavity it contains very small perforations, allowing fibers of the olfactory nerve to enter and exit. Sphenopalatine foramen located at the level of superior meatus allows communication between the nasal cavity and the pterygo-palatine fossa. Blood supply the nose has very rich vascular supply. It receives blood from both the internal and external carotid artery. Anterior and posterior ethmoidal artery are the branches of the internal carotid artery, descending to the nasal cavity through the cribriform plate. These arteries form anastomoses with each other in the anterior part of nose.

The vein of the nose follow the arteries and they drain into the pterygoid plexus, facial vein or cavernous sinus. A few nasal veins join with the sagittal sinus that is a Dural venous sinus. This is a potential pathway through which infection may spread from nose to cranial cavity. The lymph vessel drains into deep cervical node. Communication probably occur between the nasal lymphatics and subarachnoid space, probably through the sheath of the olfactory nerve.

\subsection{Nerve supply}

Olfactory nerve which provides a special sensory innervation through the cribriform plate. 
Olfactory bulb a part of the brain lies on the superior surface of the cribriform plate, above the nasal cavity. Sushrutha has described that the shrungataka marma is a sira marma, situated at the site of union of siras, supplying to the nose, ears, eyes, tongue.

\section{Physiology of nasal cavity}

The entire nasal cavity is covered by a special lining called mucosa. This mucosal surface has microscope hair like structure called cilia and many mucuous producing glands. The physiological functions of the nose include: respiration, conditioning the respired air, vocal resonance, olfaction and nasal resistance, protection of the lower airways, ventilation and drainage of the sinuses.

\section{Mode of action of sneha nasyas}

Charaka while explaining the indication for the nasya in siddhisthana has emphasized that the nasya drug usually acts through the absorption by the shringataka marma. Snehanasya after reaching the cranial cavity through nostrils removes the obstructed doshas from the cranial cavity and won't let it stay there.[10]

The absorption of these drugs is carried out in 3 ways:

1) By general blood circulation, after absorption through the mucous membrane.

2) By direct pooling in the venous sinuses of the brain via the inferior opthalmic veins.

3) By direct absorption into the CSF.

Apart from the small emissary veins entering the cavernous sinuses of the brain, a pair of venous branches emerging from the alae nasi will drain into the facial vein. These ophthalmic veins on the other hand also drain into the cavernous sinuses of the meninges, and in addition neither the facial vein nor the ophthalmic veins have any valves. Therefore, there are the more chances of the blood draining from the facial vein into the cavernous sinus in the lowered head position.

The nasal cavity directly opens in to the frontal, maxillary and the sphenoidal air sinuses. The epithelial layer is also continuous through the length. The momentary retention of the drug in the nasopharynx and the suction causes the oozing of the drug material into the air sinuses. These sites have the rich blood vessels and nerves. Vagbhata has also described that the drug administrated enters the paranasal sinuses.[11] That is the shrungataka where the ophthalmic veins and the other veins spread out. The sphenoid sinuses are in close relation with cranial structures. Thus, there may be so far the route between the air sinuses and the cavernous sinuses, which establishes the transudation of the fluid as a whole.

The action of the nasya karma depend upon the dravyas used in it. Based on it is of three types: shodana, shamana and brumhana. Shamana nasya, alleviates the doshas and help in reducing the kshobha of the marma and indriyas caused by the vitiated doshas. Brumhana nasya provides nourishment to the shiro indriya(head region) and other organs. The following paragraph explains why Ayurveda has mentioned medicated sneha dravya in a majority of the nasya karma. The nose is the highly vascular structure and it's mucus membrane provides a good absorbing surface. Hence, siddha sneha spreads along the mucous membrane. An active principle along with sneha gets absorbed inside the olfactory and respiratory mucosa and from there is carried to different places. Sneha provides nourishment to the nasal structures and other organs of the head. The network of the nasal blood and lymph vessels have many communications with those of the subdural and subarachnoid spaces. This fact is one of the important factors contributing to the extension of the mentioned drugs from the nose into the cranial cavity. The myelin is the first covering of the nerve fibre. The neuralemma is the second. The. Myelin sheeth is composed of lipud material. The blood brain barrier is highly permeable for lipid and lipid soluble substances. Therefore, these substances can pass easily through the blood brain barrier and can exert their actions. Certain lipids are used for providing energy to nervous tissues.

\section{Discussion}

Nasya dravya usually acts through the absorption by the shringataka marma and removes the obstructed doshas from the cranial cavity. Based on dravya used for nasya they are of three types: shodana, shamana, bhrumhana. An active principle along with sneha gets absorbed inside the olfactory and respiratory mucosa and from there it is carried to 
different places. Sneha provides the nourishment to the nasal structures and other organs of the head. Certain lipids are used for providing energy to the nervous tissues. Active principles in sneha nasya can reach certain levels in nervous system where they can perform their tridoshagna or kaphagna action.

\section{Conclusion}

Among Panchakarma, nasya is very important karma for the shodana of urdhva jattru. Sneha is very useful for nasya karma as it has fast and easy absorption in the mucous membrane of the nostrils. Various doshagna dravya siddhan sneha can be used for the treatment of the vyadhi according to their doshas predominance. Sneha nasya provides nourishment to the nervous system and helps in removing the impurities due to vitiated doshas.

\section{Compliance with ethical standards}

\section{Acknowledgments}

I would like to express my special thanks of gratitude to my University Sri Chandrasekarendra Saraswathi Viswamaha Vidyalaya, Kancheepuram and my College Sri Jayendra Saraswathi Ayurveda College for giving me the opportunity to write this Article.

\section{References}

[1] Dr. Anantarama S. (Reprint edition 2006). Susrhrutha Samhita of Acharya Sushruta with hindi commentary Chikitsasthana, Chaukambha Surabharati Prakashana,Varanasi, 40(21), 495.

[2] Vd Kaviraj Atridev Gupt Astangahrudaya of Acharya Vagbhata with hindi commentary,Sutrasthana (20/1),Chaukhamba Sanskrit Samsthana,Varanasi,Vi.San.2062, 127.

[3] Pt Kashinath S and Dr Gorakhnath C. (Reprint 2004). Charaka Samhita by Acharya Agnivesh with hindi commentary. Siddhisthana,(9/88),Chaukhamba Bharati Academy,Varanasi, 1070.

[4] Vd Kaviraj Atridev Gupt Ashtangahrudaya of AcharyaVagbhata with hindi commentary.,Sutrasthana (20/1),Sanskrit Sansthana, Varanasi,Vi.San, 127.

[5] Dr Anantarama S. (2006). Sushruta Samhita of Acharya Susruta with hindi commentary.,Chikitsasthana (40/22),Chaukhambhasurabharathi Prakashana,Varanasi,reprint edition, 495.

[6] Vd Kaviraj Atridev Gupt. (2006). Ashtangahrudaya of Acharya Vagbhata with Hindi commentary. Sutrasthana 21/23, Sanskrit Sansthana,Varanasi,Vi.San, 148.

[7] Kaviraj Atridev Gupt Ashtangahridaya of Acharya Vagbhata with hindi commentary by,Sutrasthana 27/9,Sanskrit Sansthana,Varanasi ,Vi.San 148.

[8] Vd Haridas and S Kasture. (1999).Ayurvediya Panchakarma Vigyana, Nasya Vidnyanaadhyaya,Shree Baidyanath Prakashana,Nagpur, 501.

[9] Richard L Drake et Gray’s Anatomy. (2005). Head and Neck Chapter, 967.

[10] Pt Kashinath Sashtri and Dr,Gorakhnath Chaturvedi. (2004). Charaka Samhita by Acharya Agnivesha with hindi commentary,Sidhisthana,(9/89), Chaukambha Bharathi Academy,Varanasi, 1070.

[11] Vd Kaviraj Atridev Gupt, Ashtangahridaya of Acharya Vagbhata with hindi commentary Chikitsasthana (21/44), Sanskrit Sansthana,Varanasi,Vi.San, 420.

\section{How to cite this article}

Roshni KP. (2020). Critical Analysis of Physiological Action of Nasya w.s.r to Sneha Nasya. World Journal of Advanced Research and Reviews, 5(2), 07-10. 